УДК 347.454 .31

DOI https://doi.org/10.32849/2663-5313/2020.8.04

Володимир Гуиуляк, канд. юрид. наук

\title{
НОВЕЛИ ПРАВОВОГО РЕГУЛЮВАННЯ ВІДНОСИН 3 ПРОВЕДЕННЯ ПРОЕКТНИХ ТА ПОШУКОВИХ РОБІТ
}

У статті акиентовано увагу на підходах до оновлення механізму правового регулювання відносин підряду на проведення проектних та пошукових робіт в сучасних умовах. Встановлено недосконалість законодавчого закріплення поняття договору на проведення проектних та пошукових робіт, де предметом договору на проведення проектних робіт визначено проектну та іншу технічну документаиію, а пошукових - безпосередньо саму роботу, а не ї результат. Окремо акиентовано увагу на порушенні в межах ст. 887 ЦК послідовності виконання таких підрядних робіт, адже пошукові роботи завжди передують проектним. Відповідно запропоновано окремо в межах двох статей § 4 визначати поняття договору підряду на проведення пошукових робіт та договору підряду на проведення проектних робіт.

Виокремлено особливості договорів підряду на проведення проектних та пошукових робіт. Обгрунтовано недоцільність у процесі оновлення ЦК України перейменування в межах § 4 гл. 61 ЦК України підрядника на вишукувача, проектувальника, виконавия тощо, зважаючи що: 1) че порушить термінологічну єдність иієі глави 61; 2) сторони в договірному порядку вправі іменувати себе і проектувальником, $і$ вишукувачем, що не заборонено.

Виявлено законодавчу прогалину у закріпленні такого важливого обов'язку замовника, як обов'язок прийняти результат проектних та пошукових робіт, та запропоновано доповнити ст. 889 ЦК Украйни иим обов'язком. Схожий висновок зроблено виходячи з аналізу обов'язку підрядника у разі необхідності погодження готової технічної документаиї̈ з уповноваженими органами державної влади та органами місиевого самоврядування (n. 4 ч. $1 \mathrm{~cm} .889 \mathrm{ma} \mathrm{n.} 2$ ч. $1 \mathrm{~cm} .890$ ЦК), запропоновано закріплення иього обов'язку виключно для проектанта за договором на проведення проектних робіт.

Піддано критииі закріплений у ст. 891 ЦК України механізм иивільно-правової відповідальності підрядника, за яким безоплатне перероблення проектно-кошторисної документаиії чи здійснення додаткових робіт віднесено до правових наслідків порушення зобов'язання. Запропоновано авторську редакиію ст. 888 ЦК України шляхом виокремлення обов'язку замовника щодо передання підряднику технічного завдання. Запропоновано доповнити § 4 гл. 61 ЦК України статтею, присвяченою механізму відповідальності замовника за допущені порушення договірних зобов'язань.

Визначено договірну відповідальність сторін у зобов'язаннях з проведення проектних та пошукових робіт через сукупність заходів впливу на боржника, що проявляється у застосуванні до останнього додаткових обтяжень, пов'язаних із невиконанням та/або неналежним виконанням ним умов договору, розмір яких відповідає розміру завданих кредитору збитків.

Ключові слова: механізм правового регулювання, договір підряду на проведення проектних та пошукових робіт, дефініція договору, предмет договору, обов'язки сторін договору, механізм цивільно-правової відповідальності, договірна відповідальність.

Постановка проблеми. Перш ніж перейти безпосередньо до розгляду питань, що потребують, на наш погляд, оновлення, насамперед зазначимо, що із закріпленої у ст. 887 ЦК України дефініції договору підряду на проведення проектних та пошукових робіт відмежування цього договору від суміжних підрядних договорів (насамперед, договору будівельного підряду) вбачається у характері робіт та їх результаті. Тобто ці роботи повинні мати характер проектно-пошукових, а їх результат відображатися у розробленій підрядником проектно-кошторисній та техніч- ній документації. Таким чином, предметом договору підряду на проведення проектних та пошукових робіт є проектно-кошторисна документація та отримані в результаті робіт дані. Зважаючи на те, що значення терміна «проєкт» надзвичайно широко використовується у різних сферах життєдіяльності людства (від математичної сфери і до сфери телерадіомовлення), в цивільно-правовій сфері під зазначеним терміном розуміється цілий комплекс проектно-кошторисної та технічної документації, зміст якої становлять вартісні, техніко-економічні обгрунтування 
доцільності проведення робіт, креслення, пояснювальні записки, технічні завдання та інші відомості, необхідні для якісного проведення проектних та пошукових робіт.

Крім цього, детальний аналіз поняття договору на проведення проектних та пошукових робіт за ЦК України дозволяє зробити висновок про недосконалість визначення результату саме пошукових робіт, адже предметом договору на проведення проектних робіт є проектна та інша технічна документація, а пошукових - безпосередньо сама робота, а не її результат. Водночас результатом пошукових робіт є відповідний документ, що містить матеріали в текстовій формі і у вигляді карт (схем), який відображає відомості про пошукові завдання, про місцезнаходження території, на якій планується здійснювати такі роботи, про види, обсяги, способи і строки проведення пошукових робіт, про результати комплексного вивчення природних i техногенних умов зазначеної території, в тому числі про результати вивчення, оцінки та прогнозу можливих змін природних і техногенних умов зазначеної території та повинен містити оцінку впливу виконання інших робіт (будівельних, видобувних тощо) на навколишнє середовище та інші об'єкти, що розміщені поруч.

Разом із тим доцільно підтримати зроблені у вітчизняній цивілістиці висновки щодо порушення послідовності виконання таких підрядних робіт, адже пошукові роботи завжди передують проектним, i ïx дані є необхідними для проектування конкретного об'єкта будівництва. Виправдати зазначене формулювання назви договору можна хіба що усталеною практикою іiї використання [1, с. 219]

Справді, сьогодні поширеними на практиці є випадки, коли підрядник, проводячи пошукові роботи, доходить висновку про неможливість проведення, наприклад, у цьому місці будівництва (наявність грунтових вод, знахідки, що свідчать про історичну цінність цього місця, тощо), відповідно, і доцільність розробки проектно-кошторисної та іншої технічної документації відсутня. Зважаючи на це, за договором підряду на проведення проектних та пошукових робіт можуть проводитися як проектні та пошукові роботи разом одним підрядником, так і пошукові та проектні роботи окремо [2, с. 30].

Аналізуючи вищенаведені точки зору, вважаємо за доцільне розмежувати ці договори на законодавчому рівні шляхом, зважаючи, що пошукові роботи передують проектним, закріплення у ч. 1 ст. 887 ЦК України визначення поняття договору підряду на проведення пошукових робіт, а в ч. 2 ст. 887 ЦК
України - визначення поняття договору підряду на проведення проектних робіт:

«1. За договором підряду на проведення пошукових робіт підрядник зобов'язується на свій ризик за завданням іншої сторони (замовника) провести пошукові роботи та передати їх результатзамовнику, азамовникзобов'язується передати технічне завдання та інші вихідні дані підряднику, прийняти та оплатити результат пошукових робіт.

2. За договором підряду на проведення проектних робіт одна сторона (підрядник) зобов'язується за завданням іншої сторони (замовника) розробити проектно-кошторисну та/або іншу технічну документачію, а замовник зобов'язується передати завдання на проектування та інші вихідні дані підряднику, прийняти та оплатити їх.

3. До договорів підряду на проведення проектних та пошукових робіт застосовуються загальні положення про підряд, якщо інше не встановлено законом».

Отже, особливостями договорів підряду на проведення проектних та пошукових робіт є: 1) характер роботи (пошукові та проектні роботи) та її результату (дані, отримані внаслідок пошукових робіт, та проектнокошторисна документація); 2) виконання робіт на підставі вихідних даних на проведення пошукових робіт та для проектування; 3) проведення робіт без використання матеріалу [3, с. 135].

Виклад основного матеріалу. Як і у будьякому підрядному договорі, сторонами договору підряду на проведення проектних та пошукових робіт виступають замовник і підрядник. Законодавець в усій гл. 61 ЦК України для позначення виконавця будьяких робіт оперує терміном «підрядник».

Разом із тим у цивілістичній літературі трапляється й інше найменування підрядника в досліджуваному договорі - вишукувач [4, с. 248] або проектувальник [5, с. 53]. Обгрунтовується така позиція тим, що це дасть змогу дізнатись, який вид робіт виконуватиметься за договором, без вивчення предмета договірного зобов'язання.

Недоцільність у процесі оновлення ЦК України перейменування в межах § 4 гл. 61 ЦК України підрядника на вишукувача, проектувальника, виконавця тощо позбавлене логічного обгрунтування, зважаючи, що: 1) це порушить термінологічну єдність цієї глави, де у всіх видах договорів підрядного типу використовується термін «підрядник», а щодо одного договору - зовсім інший термін; 2) сторони в договірному порядку вправі іменувати себе і проектувальником, і вишукувачем, що не лише не заборонено законодавством, а й дозволено ним; 3) щодо можливості 
дізнатись, які саме роботи виконує підрядник - проектні чи пошукові, за найменуванням підрядника проектантом чи вишукувачем, то така інформація міститься у предметі кожного договірного зобов'язання. А тому зайве переобтяження цивільного законодавства видається недоцільним та таким, що суттєво не впливає на покращення прав сторін за договором підряду на проведення проектних та пошукових робіт

У положеннях § 4 гл. 61 ЦК України міститься низка вимог, що конкретизують основний обов'язок підрядника з виконання роботи. Мається на увазі, що підрядник зобов'язаний виконати роботу якісно та відповідно до технічного завдання та вихідних даних, на власний ризик, у встановлений строк; погоджувати результати робіт із замовником, а у разі необхідності - також 3 уповноваженими органами державної влади та органами місцевого самоврядування; повторно використовувати результати робіт лише за згодою підрядника; не передавати їх без згоди замовника іншим особам, гарантувати замовникові відсутність у інших осіб права перешкоджати або обмежити виконання робіт на основі підготовлених за договором результатів робіт тощо.

Щодо обов'язку підрядника передати замовнику результати проектних та пошукових робіт слід зазначити, що наведеним обов'язком охоплюється їх підготовка, погодження готової технічної документації із замовником, за необхідності - погодження 3 компетентними державними органами, органами місцевого самоврядування та безпосередньо передача результату таких робіт, що оформлюється актом приймання-передачі. Разом із тим наведеному обов'язку підрядника кореспондує закріплений у законодавчій дефініції договору підряду на проведення проектних та пошукових робіт обов'язок замовника прийняти їх результат. Тобто в процесі передачі та прийняття результату пошукових робіт беруть участь обидві сторони. Разом із тим такий важливий обов'язок замовника незрозуміло з яких причин випущений законодавцем у переліку обов'язків замовника, що закріплені в ст. 889 ЦК України. Зважаючи на наведене, вважаємо за доцільне закріпити такий обов'язок замовника шляхом доповнення ст. 889 ЦК України таким текстом: «1) npuйняти результати пошукових та/або проектних робіт у строки, погоджені сторонами, за умови відсутності відступів від умов договору або інших недоліків».

Щодо обов'язку підрядника у разі необхідності погодження готової технічної документації з уповноваженими орга- нами державної влади та органами місцевого самоврядування одразу ж зауважимо про допущені законодавчі помилки (п. 4 ч. 1 ст. 889 та п. 2 ч. 1 ст. 890 ЦК), які полягають у закріплені цього обов'язку виключно для проектанта за договором на проведення проектних робіт. Разом із тим цілком зрозуміло, що такий обов'язок поширюється і на підрядника за договором на проведення пошукових робіт, оскільки, як і замовник повинен перевірити їх відповідність технічному завданню, так і в окремих випадках уповноважені органи державної влади та органи місцевого самоврядування повинні перевірити іх відповідність вимогам технічних регламентів i завданням для проведення пошукових робіт. Зважаючи на це, вважаємо за доцільне уточнити п. 4 ч. 1 ст. 889 та п. 2 ч. 1 ст. 890 ЦК України і викласти у таких редакціях:

- п. 4 ч. 1 ст. 889 ЦК України: «брати участь разом із підрядником у погодженні готової проектно-технічної документаиї та результатів пошукових робітіз уповноваженими органами державної влади та органами місиевого самоврядування»;

- п. 2 ч. 1 ст. 890 ЦК України: «погоджувати готову проектно-кошторисну документацію та результати пошукових робіт із замовником, а в разі необхідності - також із уповноваженими органами державної влади та органами місиевого самоврядування».

Однимізобов’язківпідрядника, щовипливає зі змісту ч. 2 ст. 888 та п. 1 ч. 1 ст. 890 ЦК України, є обов'язок попередити замовника про обставини, що перешкоджають виконанню проектних та пошукових робіт, а також про невідповідність технічної документації замовника та інших вихідних даних вимогам чинного законодавства. Одразу ж зазначимо відсутність законодавчого закріплення зазначеного обов'язку в ст. 890 ЦК України, тому таку вимогу доцільно закріплювати в договірному порядку.

Підсумовуючи розгляд прав та обов'язків підрядника за договором підряду на проведення проектних та пошукових робіт, слід наголосити на доцільності у процесі оновлення гл. 61 ЦК України редагування ст. 890 ЦК України як такої, що присвячена визначенню обов'язків підрядника за договором підряду на проведення проектних робіт без урахування особливостей досліджуваного договору:

«Стаття 890. Обов'язки підрядника

1. Підрядник зобов'язаний:

1) виконувати роботи відповідно до технічного завдання та вихідних даних для проведення проектних та/або пошукових робіт та згідно з договором; 
2) погоджувати готову проектно-кошторисну документаиію та/або результати пошукових робіт із замовником, а в разі необхідності - також з уповноваженими органами державної влади та органами місиевого самоврядування;

3) передати замовникові готову проектно-кошторисну документацію та/або результати пошукових робіт;

4) повторно використовувати проектнокошторисну документачію та/або результати пошукових робіт лише за згодою підрядника;

5) не передавати без згоди замовника проектно-кошторисну документачію та/або результати пошукових робіт іншим особам;

6) гарантувати замовникові відсутність у інших осіб права перешкодити або обмежити виконання робіт на основі підготовленої за договором проектно-кошторисної документаиії та/або результатів пошукових робіт».

Аналізуючи права та обов'язки замовника за договором на проведення проектних та пошукових робіт, насамперед зазначимо, що основними обов'язками замовника є обов'язок передати підрядникові завдання на проведення таких робіт та необхідні для цього вихідні дані, прийняти виконану роботу, оплатити ï. Слід відзначити важливість попереднього погодження між сторонами завдання та усіх вихідних даних, оскільки надалі проектні та пошукові роботи повинні виконуватись у повній відповідності до тих вимог, які погоджені контрагентами Відступи від них заборонені, крім випадків їх погодження між контрагентами договору.

Зважаючи на це, вважаємо за доцільне редагувати ст. 888 ЦК України шляхом виокремлення обов'язку замовника щодо передання підряднику технічного завдання.

За порушення сторонами взятих договірних умов передбачено цивільно-правову відповідальність, що має майновий характер та проявляється у застосуванні до порушника додаткових майнових обтяжень, розмір яких за загальним правилом повинен відповідати розміру понесених кредитором збитків. У рамках договору підряду на проведення проектних та пошукових робіт порушення договору підрядником може полягати у невиконанні чи неналежному виконанні своїх зобов'язань, що закріплені безпосередньо у договорі, нормативно-правових актах, технічних нормах чи технічному завданні. Натомість порушення замовника полягає у неприйнятті результату робіт, несплаті підрядникові встановленої ціни, розголошенні відомостей, що містять таємницю, без згоди підрядника, ненаданні передбачених договором чи законом послуг підрядникові тощо.
Особливістю регламентації цивільноправової відповідальності підрядника за неналежне виконання своїх зобов'язань за договорами підряду на проведення проектних та пошукових робіт є відсутність конкретних санкцій у чинному законодавстві України. Так, у § 4 гл. 61 ЦК України цивільно-правовій відповідальності присвячена лише одна стаття, що стосується питань відшкодування збитків виключно за недоліки, допущені підрядником під час проведення проектних та пошукових робіт.

Зі змісту цієї статті випливає, що особливістю відповідальності підрядника $є$ те, що підрядник несе відповідальність після приймання-передачі результатів робіт за договором, у тому числі в ході будівництва, а також у процесі експлуатації об'єкта, створеного на підставі даних проектних та пошукових робіт. У разі виявлення недоліків у результатах таких робіт підрядник на вимогу замовника зобов'язаний безоплатно здійснити необхідні додаткові роботи, а також відшкодувати замовникові завдані збитки, якщо законом або договором не встановлено інше. Тобто законодавець по-іншому порівняно із загальними положеннями про підряд підходить до вирішення питання про відповідальність підрядника за договорами підряду на проведення проектних та пошукових робіт. Основна відмінність тут вбачається у тому, що підрядник відповідає за недоліки результату робіт, виявлені як у ході будівництва, так і в процесі експлуатації цього об'єкта у майбутньому, а особливість регламентації цивільно-правової відповідальності підрядника відображається у відсутності конкретних санкцій у § 4 гл. 61 ЦК України [6, с. 204].

Із цього приводу викликає подив відображене у ч. 2 ст. 891 ЦК України положення, за яким безоплатне перероблення проектно-кошторисної документації чи здійснення додаткових робіт віднесено до правових наслідків порушення зобов'язання. Тут доцільно наголосити, що такий наслідок не передбачений у загальних положеннях про відповідальність за порушення зобов'язань. Більше того, оскільки сутність цивільно-правової відповідальності полягає у покладенні на боржника певних обтяжень, що проявляються в додатковому обов'язку останнього, слід зауважити, що безоплатне здійснення необхідних додаткових робіт не є додатковим обов'язком підрядника, оскільки тут йдеться про виконання останнім основного зобов'язання належним чином. Тому безоплатне здійснення необхідних додаткових робіт за цими різновидами договору підряду не слід розглядати як форму відповідальності, а положення ч. 2 ст. 891 ЦК України потребує редагування. 
Крім того, особливість цивільно-правової відповідальності підрядника відображається також й у можливості її настання після припинення дії договору на проведення проектних та пошукових робіт. Звідси виникає питання про природу таких відносин, адже договірні відносини припинені, однак до підрядника звертаються треті особи чи сам замовник із вимогами про відшкодування збитків. Наведені відносини в європейській правовій доктрині іменуються як постдоговірна відповідальність (culpa post contractum finitim), сутність якої зводиться до покладення на колишнього учасника договірних відносин додаткового обов'язку, який він повинен буде виконувати на користь свого колишнього контрагента протягом невизначеного періоду часу, і в разі його порушення він несе цивільноправову відповідальність [7, с. 49].

Така довготривала можливість притягнення до цивільно-правової відповідальності підрядника дозволяє зробити висновок про особливі умови відповідальності останнього за завдані збитки, спричинені допущеними недоліками результату пошукових робіт. Зважаючи на наведене, пропонуємо до особливих правовідносин із притягнення підрядника до цивільної відповідальності за завдані збитки, спричинені допущеними недоліками результату пошукових робіт, застосовувати строки позовної давності за аналогією із ч. 3 ст. 322 ГК України, а саме: 10 років - у разі, якщо недоліки не могли бути виявлені у ході будівництва; 30 років - щодо відшкодування збитків, завданих замовникові чи третім особам протиправними діями підрядника, що призвели до руйнувань чи аварій [6, с. 206].

Не позбавлена недоліків і сама ст. 891 ЦК України, в ч. 1 якої не зрозуміло, з яких причин спочатку зазначається результат проектних робіт, і аж потім самі пошукові роботи. Водночас далі в цій самій частині законодавець вже оперує терміном «результати пошукових робіт». Не позбавлена термінологічних недоліків і ч. 2 ст. 891 ЦК України, в якій зазначається, що у разі виявлення недоліків у проектно-кошторисній документації або в пошукових роботах підрядник на вимогу замовника зобов'язаний безоплатно переробити проектно-кошторисну документацію або здійснити необхідні додаткові пошукові роботи, а також відшкодувати завдані збитки, якщо інше не встановлено договором або законом.

Крім того, ст. 891 ЦК України присвячена лише відповідальності підрядника за недоліки документації та робіт. Із цього випливає висновок, що законодавець залишає на розсуд сторін визначення наслідків інших порушень зобов'язань. Разом із тим окре- мого закріплення у вищенаведеній статті ЦК України потребує питання відповідальності підрядника за порушення під час проведення проектних та пошукових робіт законодавчих вимог про охорону навколишнього природнього середовища та про безпеку проведення таких робіт. На нашу думку, доцільно в межах § 4 гл. 61 ЦК України передбачити відповідальність підрядника за порушення зазначених вимог. Така доцільність аргументується хоча б тим, що характер проектних та пошукових робіт досить часто пов'язаний iз безпосереднім вторгненням у природне середовище (вивчення геологічних розрізів, буріння пошукових свердловин, забір води тощо) або з діяльністю, що пов'язана із небезпекою для оточення (вибухові роботи, підземне, підводне буріння тощо). 3 огляду на це, на нашу думку, слід доповнити ст. 891 ЦК України бланкетною нормою із закріпленням відповідальності підрядника за порушення під час проведення проектних та пошукових робіт законодавчих вимог про охорону навколишнього природнього середовища та про безпеку проведення таких робіт.

У § 4 гл. 61 ЦК України також містяться окремі положення, що закріплюють можливість притягнення замовника до цивільноправової відповідальності за: а) не передання або прострочення передання підрядникові технічних завдань та інших вихідних даних; б) використання результатів проектних та пошукових робіт в цілі, не передбачені договором (п. 2 ч. 1 ст. 889 ЦК); в) передання результатів робіт іншим особам і розголошення даних, що містяться у ній, без згоди підрядника (п. 2 ч. 1 ст. 889 ЦК); г) ненадання послуг підрядникові при проведенні проектних та пошукових робіт в обсязі та на умовах, встановлених договором; г) неприйняття участі разом з підрядником у погодженні результатів робіт з уповноваженими органами державної влади та органами місцевого самоврядування; д) відмову у відшкодуванні підрядникові додаткових витрат, пов'язаних зі зміною вихідних даних для проведення проектних та пошукових робіт внаслідок обставин, що не залежать від підрядника тощо. Зважаючи на це, вважаємо за доцільне в межах оновлення цього параграфу гл. 61 ЦК України доповнити його статтею, присвяченою механізму відповідальності замовника за допущені порушення договірних зобов'язань.

Такі міркування щодо доцільності доповнення § 4 гл. 61 ЦК України статтею про відповідальність замовника за допущені порушення договірних зобов'язань пояснюються нагальною потребою в усуненні прогалини в правовому регулюванні відносин за цим договором, адже ЦК України натепер є єдиним норма- 
тивно-правовим актом, що має юридичну силу закону, який врегульовує договірні відносини щодо проведення проектних та пошукових робіт [8, с. 169]. Схожий підхід щодо відповідальності замовника за договором будівельного підряду закріплений у ст. 886 ЦК України «Відповідальність замовника».

\section{Висновки}

Отже, підсумовуючи вищенаведене, пропонуємо визначати договірну відповідальність сторін у зобов'язаннях з проведення проектних та пошукових робіт через сукупність заходів впливу на боржника, що проявляється у застосуванні до останнього додаткових обтяжень, пов'язаних із невиконанням та/або неналежним виконанням ним умов договору, розмір яких відповідає розміру завданих кредитору збитків.

\section{Список використаних джерел:}

1. Цивільне право України : підручник у 2-х кн. / О. В. Дзера (керівник авт. кол.), Д. В. Боброва, А. С. Довгерт та ін.; за ред. О. В. Дзери, Н. С. Кузнєцової. 2-е вид., доп. і перероб. Київ: Юрінком Інтер, 2005. Кн. 2. С. 219
2. Диба О. В. Договір підряду на проведення проектних робіт за цивільним законодавством України : дис. ... канд. юрид. наук: 12.00.03. Київ, 2018. С. 30

3. Окремі види договорів у сучасному законодавстві України : колективна : монографія / за заг. ред. О. С. Кізлової, О. С. Кужко, Л. В. Діденко. Одеса : Айс-Принт, 2017. С. 135.

4. Юридична енциклопедія : в 6 т. / редкол.: Ю. С. Шемшученко (голова редкол.) та ін. Київ: «Укр. енцикл.», 1998. Т. 5: П-С. 2003. С. 248.

5. Лукасевич-Крутник I. С. Договір підряду на проведення проектних та пошукових робіт : монографія. Тернопіль: ВПЦ «Економічна думка $\mathrm{THEY}_{\gg, 2012 .}$ C. 53.

6. Гуцуляк В. К. Договір підряду на проведення пошукових робіт за цивільним законодавством України : монографія. Київ, 2017. С. 204, 206, 213-214.

7. Синявская М. С. Вопросы нарушения договора и его последствий в современном французском праве: настоящее положение дел, критика, проект реформы. Вестник гражданского права. 2008. № 3. С. 49.

8. Лукасевич-Крутник I. C. Договір підряду на проведення проектних та пошукових робіт : дис. ... канд. юрид. наук: 12.00.03. Львів, 2011. C. 169.

Volodymyr Hutsulyak. Amendments to the legal regulation of relations related to the implementation of project and exploration works

The article focuses on approaches to renewal the mechanism of legal regulation of contractual relations for design and exploration works in modern conditions. The imperfection of the legislative consolidation of the concept of the contract for design and exploration works is established, where the subject of the contract for design works is design and other technical documentation, and exploration - directly the work itself, not its result. Special attention is paid to the violation within Art. 887 of the Civil Code the sequence of performance of such contract works, inasmuch as exploration works always precede design ones.

The peculiarities of contracts for design and exploration works are singled out. The inexpediency of renaming contractor for a surveyor, designer etc. within the limits of $\S 4$ of ch. 61 of the Civil Code of Ukraine, given that: 1) it violates the terminological unity of this chapter; 2) the parties have the contractual right to call themselves both the designer and the searcher, which is not prohibited.

A legislative gap has been identified in enshrining such an important duty of the customer as the obligation of the customer to accept the results of design and exploration work and it is proposed to supplement Art. 889 of the Civil Code of Ukraine with this obligation. A similar conclusion was made in the analysis of the contractor's duty in case of need to coordinate the finished technical documentation with the state authorities and local governments (paragraph 4, part 1 of Article 889 and paragraph 2, part 1 of Article 890 of the Civil Code), by consolidating this obligation exclusively for the designer under the contract for design work.

The mechanism of civil liability of the contractor enshrined in Art. 891 of the Civil Code of Ukraine, according to which free processing of design estimates or additional work is attributed to the legal consequences of breach of obligation, is subjected to criticism. The author's version of Art. 888 of the Civil Code of Ukraine is proposed by separating the obligation of the customer to transfer to the contractor terms of reference. It is proposed to supplement $\S 4$ of ch. 61 of the Civil Code of Ukraine article on the mechanism of liability of the customer for breaches of contractual obligations.

The contractual liability of the parties in the obligations with carrying out design and exploration works through a set of measures to influence the debtor is determined, which is manifested in the application to the latter of additional burdens associated with non-performance and / or improper performance of the contract, the amount of which corresponds to the damage to the creditor.

Key words: mechanism of legal regulation, contract for design and exploration works, definition of the contract, subject of the contract, obligations of the parties to the contract, mechanism of civil liability, contractual liability. 